\title{
Intracoronary delivery of bone-marrow-derived stem cells
}

\author{
Quang T Bui, Zachary M Gertz and Robert L Wilensky*
}

\begin{abstract}
Ischemic heart disease is the single greatest killer of Americans and its complications are a major cause of congestive heart failure and ventricular arrhythmias while significantly contributing to increased health care costs and reduced patient quality of life. Advances in medical therapy, although significant over the past decade, are still inadequate in regards to targeting the prime underlying pathology, the irreversible loss of damaged or dead cardiomyocytes. Research into the use of cell transplantation therapy to treat cardiac diseases, with the goal of improving cardiac function, shows promise. The aim of this review will be to discuss the potential therapeutic effects of myocardial stem cell and progenitor cell therapy delivered by an intracoronary route with special reference to treatment of infarcted myocardium.
\end{abstract}

\section{Introduction}

Ischemic heart disease is the leading cause of death in developed countries [1]. While survival has improved following a myocardial infarction, significant, irreversible loss of myocardial tissue often leads to congestive heart failure, ventricular arrhythmias and increased disability. It is estimated that 5 million people in the USA are affected by heart failure, with $60 \%$ of cases attributed to ischemic heart disease, at a cost of $\$ 35$ billion per year to society $[2,3]$. Because the reproductive capacity of cardiomyocytes is limited, cellular cardiomyoplasty, defined as the delivery of donor stem or progenitor cells into the myocardium with the goal of improving cardiac function, is a potential approach to replace damaged or dead myocytes and improve cardiac function. To date, a large number of clinical studies have examined the potential

*Correspondence: Robert.wilensky@uphs.upenn.edu

Cardiovascular Division, Hospital of the University of Pennsylvania and

Cardiovascular Institute, University of Pennsylvania, 3400 Spruce Street, Philadelphia, PA 19104, USA therapeutic effects of myocardial stem cell therapy [4-7]. This review aims to provide an overview of the modes of delivery of bone-marrow-derived stem/progenitor cells to the myocardium, with particular reference to percutaneous routes of delivery after a myocardial infarction.

\section{Bone marrow cells}

Various cell types have been tested experimentally for cardiac repair and include bone-marrow-derived cells (BMCs), skeletal myoblasts, placental/cord-blood-derived cells, adipose-tissue-derived cells, resident cardiac progenitor cells, embryonic stem cells and, recently, induced pluripotent stem cells $[8,9]$. Because of the ease of isolation and expansion and the avoidance of allogeneic incompatibility issues, BMCs and skeletal myoblasts of autologous origin have been the major cell types evaluated in clinical trials.

BMCs are a heterogeneous population of cells consisting of approximately $98 \%$ differentiated cells and approximately $2 \%$ stem or progenitor cells, which include hematopoietic stem cells, endothelial progenitor cells and mesenchymal stem cells (MSCs). Bone-marrow-derived stem or progenitor cells have been demonstrated to be able to trans-differentiate into various cell types of the body, including cardiomyocytes [10-12]. Like skeletal myoblasts, BMCs can be readily harvested from patients and expanded $e x$ vivo for autologous transplantation, and BMC transplantation in ischemic animal models has resulted in improvement in cardiac function $[13,14]$. Mechanistically, paracrine effects promoting neoangiogenesis have been the major purported mechanism responsible for clinical improvements in cardiac function indices [15-18].

\section{Cell delivery modes}

Optimal cell therapy depends on successful delivery into the myocardial area of need, engraftment of a sufficient concentration of cells and prolonged survival of the transplanted cells. While cells have been delivered and a biological effect has been observed, the optimal stem/ precursor cell to use, the number of cells required, the timing of transplantation post-infarction, and the optimal cellular milieu and delivery route have yet to be 
determined. Indeed, cells have been delivered via a number of routes: intravenous, intracoronary, intramyocardial, and intrapericardial. Few studies have compared these approaches (to be discussed below) and questions remain regarding the optimal approach.

\section{Intravenous delivery}

The intravenous technique, through either a peripheral or central venous catheter, is the simplest delivery mode and avoids the risk of an invasive procedure. However, it is the least efficacious delivery method since a high percentage of infused cells may become sequestered in the lung, liver, spleen or other organs, allowing only a small number of cells to actually enter the coronary circulation, where they must still transverse the arterial or capillary wall [19]. Moreover, this route is not amenable for patients with occluded arteries, unless there are sufficient routes of collateral coronary artery circulation.

\section{Intracoronary delivery}

Selective intracoronary cell delivery involves cell infusion, generally through the central lumen of a balloon catheter positioned in the coronary artery. Cells can be injected while either maintaining coronary flow or following interruption of flow with balloon occlusion to minimize rapid cell washout. An intracoronary approach allows for selective delivery of cells to the myocardial area of interest (Figure 1) and theoretically limits risks of systemic administration. Indeed, delivery is more concentrated in ischemic and border zone regions (Figure 2). Coronary delivery requires that the target myocardium be subtended by a patent coronary artery or identifiable collateral vessel and so is performed following percutaneous coronary intervention (PCI). Intracoronary infusion has been used in patients with ST-segment elevation myocardial infarction or chronic myocardial ischemia [20]. With any transvascular delivery approach, cell retention ultimately requires transendothelial passage and migration into the myocardium.

\section{Intramyocardial delivery}

Cells can be injected directly into the myocardium via a transepicardial or transendocardial injection. Such direct injection techniques have been used in patients presenting with an ischemic cardiomyopathy when an occluded coronary artery limits transvascular cell delivery, often as an adjunct during coronary artery bypass grafting. While an epicardial approach allows for direct visualization of the infarcted myocardium for accurate targeting of cell injections, it requires open-heart surgery with its attendant risks.

Targeted injections can also be obtained by an endocardial approach, which obviates the need for surgery and has been applied as a stand-alone procedure.
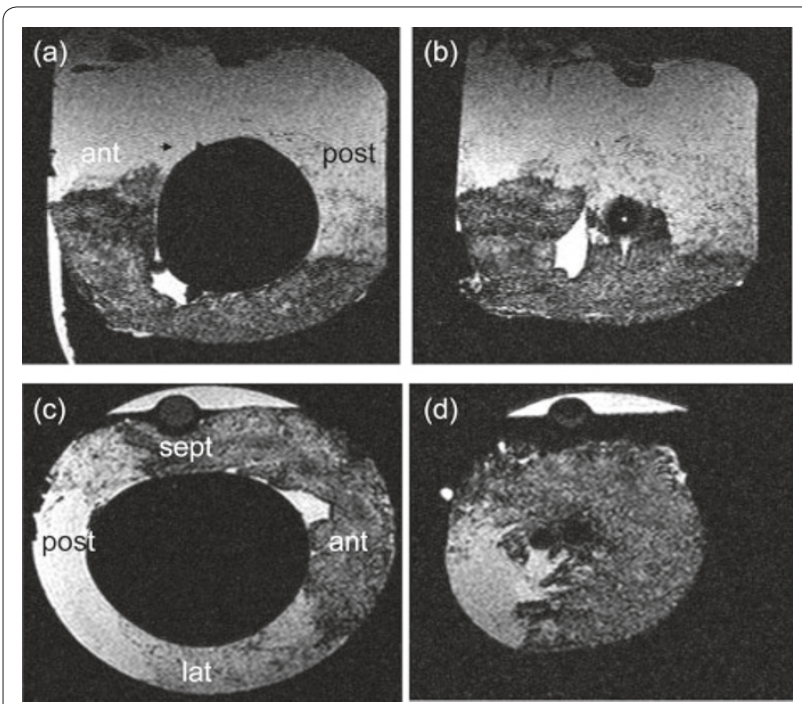

Figure 1. One hour after reperfusion following a myocardial infarction $4.1 \times 10^{7}$ mesenchymal stem cells labeled with iron nanoparticles were delivered into the mid left anterior descending coronary artery of pigs. (a-d) Sagittal (a,b) and transverse $(c, d)$ views from a post-mortem high-resolution magnetic resonance imaging scan show increased concentrations of iron particles within the mid wall (c) and distal septal (sept) and anterior (ant) walls (d). Lat, lateral wall; post, posterior.

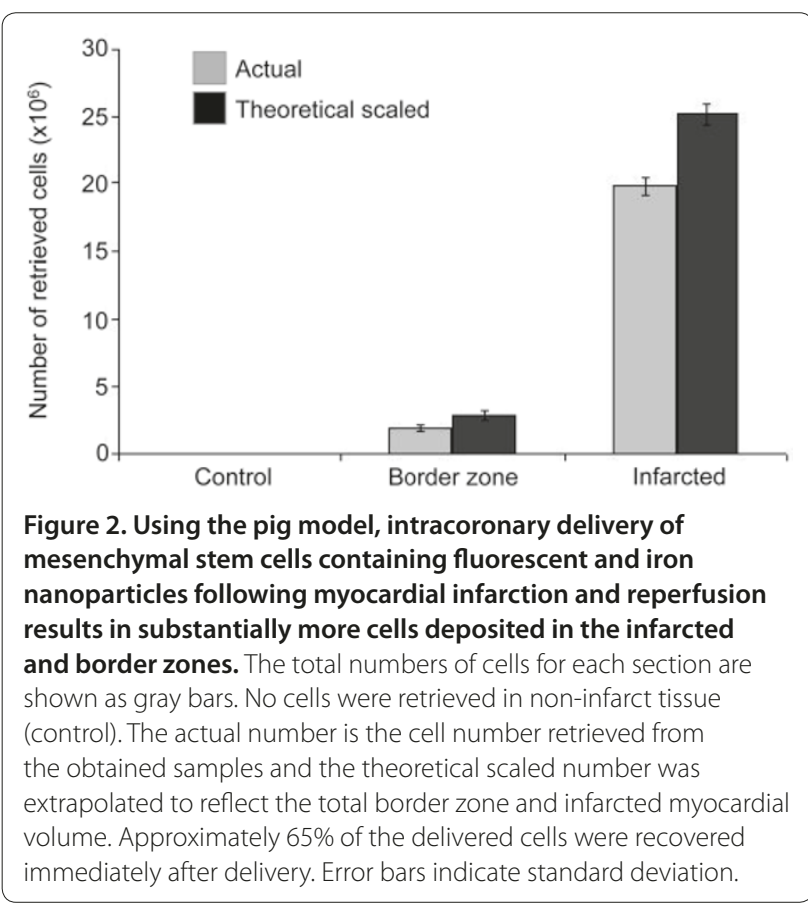

The lack of direct visualization with the endocardial approach has led to the development of specialized catheters that utilize electromechanical mapping systems for the identification of areas of interest, such as hibernating or infarcted tissue or tissue on the border zone of 
ischemic/infarcted and non-ischemic tissue [21]. A limitation of both epicardial and endocardial approaches is the risk of perforation.

\section{Retrograde coronary sinus delivery}

An emerging intravenous mode via a retrograde coronary sinus delivery approach may prove efficacious [22]. Following catheter placement into the coronary sinus, a balloon infusion catheter is placed, the balloon inflated and cells administered by infusion at pressures $20 \mathrm{ml}$ higher than the coronary sinus pressure, allowing for retrograde perfusion of cells into the myocardium. The percutaneous retrograde coronary sinus delivery method has been well studied in the delivery of proteins and genes in preclinical models and appears to provide for more homogenous delivery across the myocardium [23]. Like intracoronary delivery, cells must transverse the vessel wall.

\section{Intrapericardial delivery}

Intrapericardial delivery of cells is the least studied delivery approach. An advantage of a pericardial approach is that a large number of cells can be deposited and retained with the potential for enhanced bioavailability of infused cells. However, migration of cells across the visceral pericardium into the myocardium is necessary. Small preclinical studies suggest that such delivered BMCs home to the infarct site [24]. Little is known about the efficiency and efficacy of cells delivered via this approach and future studies will be needed to clarify its usefulness.

\section{Comparison of delivery methods}

Currently no delivery strategy has emerged as the most optimal administration route for cellular cardiomyoplasty and to date there are no head to head clinical comparisons of the different delivery routes. Large animal models have been useful in this regard. Immediately following delivery of peripheral blood mononuclear cells 6 days after myocardial infarction, more cells are observed in the myocardium after intramyocardial $(11 \pm 3 \%)$ compared to intracoronary $(2.6 \pm 0.3 \%)$ or retrograde coronary venous delivery $(3.2 \pm 1 \%)$. All three approaches, however, resulted in a significant fraction of cells entering into the pulmonary circulation (intracoronary, $47 \pm 1 \%$; intramyocardial, $26 \pm 3 \%$; retrograde, $43 \pm 3 \%$ ) [25]. Freyman and colleagues [26] published data comparing intravenous, intracoronary, and endocardial delivery of MSCs immediately following infarction in a porcine model. Cellular engraftment was ascertained 14 days later in order to solely evaluate the short-term retention and engraftment of cells. Intracoronary delivery of MSCs was associated with a significantly greater number of engrafted MSCs compared to either percutaneous endocardial delivery or intravenous delivery. However, in all three groups the percentage of retained/engrafted cells was low (intravenous, $0 \%$; intracoronary, $6 \%$; endocardial, $3 \%)$. Whereas endocardial delivery was safe and well tolerated, intracoronary delivery was associated in almost half of the deliveries with a higher incidence of decreased distal coronary blood flow. Histologic evaluation demonstrated plugging of capillaries and arterials in the infarcted area due to the MSCs in association with red blood cells and neutrophils. Endocardial delivery was associated with decreased cell engraftment in the pulmonary tissue while the intravenous approach, not surprisingly, was associated with the highest pulmonary engraftment rate.

Follow-up studies have evaluated the effect of intracoronary perfusion protocols on subsequent coronary blood flow in the infarcted pig model [27]. Three protocols were evaluated: five serial 2-ml infusions, with the balloon inflated for 2 minutes, followed by 2 minutes of reperfusion; a single $10-\mathrm{ml}$ infusion, with the balloon inflated, over 10 seconds $(60 \mathrm{ml} /$ minute); and a single 10 - $\mathrm{ml}$ infusion over 30 seconds $(20 \mathrm{ml} /$ minute). The results showed that serial infusions were associated with substantially decreased distal blood flow. Persistent decreased blood flow was noted at 14 days in half the animals in the serial infusion group and only $17 \%$ of those in the single infusion groups. The decreased distal coronary blood flow was associated with a significantly increased mortality rate in the serial infusion animals. These observations correlate with what is known clinically: that no reflow (following PCI) is a predictor of poor outcomes [28]. Others have also shown extensive plugging of the microvasculature following delivery of MSCs using serial infusions in a canine model 7 days after infarction [29]. In that study an association between increased velocity of intracoronary infusion and microinfarcts in non-infarcted dogs was observed. Vulliet and colleagues [30] observed that the delivery of mesenchymal stromal cells in healthy, non-infarcted dogs caused electrocardiographic ST changes, microvascular plugging and microinfarcts. Taken together, these data suggest that either eliminating sequential balloon inflations and/or increasing the time between myocardial reperfusion and intracoronary delivery may be necessary to reduce no-reflow.

The association of bone-marrow-derived stem cells with subsequent decreased distal blood flow has not been observed in humans, which may reflect the increased time between infarction and cell delivery in humans compared to animals [31-35]. In the initial clinical demonstration of intracoronary BMC delivery into the necrotic zone there were no complications or side-effects (although the possible complications were not listed) in 10 patients infused 5 to 9 days after onset of infarction with $1.5 \times 10^{6}$ to $4 \times 10^{6}$ mononuclear cells [34]. Timing 
of cell delivery may play a role in the variant findings. In clinical studies, delivery of cells occurs 1 to 8 days after infarction, while in pre-clinical studies injection often occurs immediately following infarction. This delay may allow for a more complete recovery of microvascular function and a reduction in the interstitial edema that occurs following recanalization of an infarct-related artery, both of which are likely to impede successful cell engraftment $[31,36]$. Also, it should be noted that MSCs are relatively large cells $(10$ to $20 \mu \mathrm{m})$ and the future use of smaller cells may be less likely to cause microvascular plugging and decreased distal blood flow.

\section{Intracoronary cell therapy in patients}

The ease and safety of catheter-based interventions in patients with acute and chronic ischemic heart disease has made the intracoronary cell delivery approach the clinical method of choice. A common feature of many preclinical and early clinical studies involving cellular cardiomyoplasty is the short-term benefit in terms of improvement in one or more endpoints: ejection fraction, ventricular volumes, infarct size and myocardial perfusion.

In the BOOST trial (BOne marrOw transfer to enhance ST-elevation infarct regeneration) [32], 60 patients were randomly assigned to standard therapy versus $2.4 \times 10^{9}$ nucleated BMC transfer via intracoronary delivery an average of 4.8 days after primary PCI. Cardiac function was assessed with magnetic resonance imaging (MRI) prior to and 6, 18, and 61 months after cell transfer. The results showed short-term improvement in left ventricular contractility within the infarct border zone and a $6 \%$ improvement of global left ventricular ejection fraction at 6 months in the experimental group compared to the control group. However, the improvement was not observed at either 18 or 61 months.

The Leuven acute myocardial infarction (AMI) trial enrolled 67 patients randomly assigned to receive $4.8 \times 10^{8}$ mononucleated BMCs or placebo within 24 hours of primary PCI [31]. MRI assessment of left ventricular ejection fraction at 3 to 4 days and 4 months did not demonstrate an improvement with cell therapy. However, there was a greater reduction in infarct volume after 4 months, assessed by serial MRI in the cell therapy group with improvement in regional contractility. In the REPAIR-AMI trial (REinfusion of enriched Progenitor cells And Infarct Remodeling in Acute Myocardial Infarction), 187 patients were randomly assigned to receive placebo or $2.4 \times 10^{8}$ mononucleated BMCs at a mean of 4.4 days after primary PCI [37]. Ventricular function was found to improve by an average of $2.5 \%$ as assessed by contrast angiography at 4-month follow-up when compared to controls.

In the FINCELL (FINnish stem CELL study) trial, 80 patients with an AMI initially treated with thrombolytic therapy followed by PCI were randomized to either placebo or cell therapy with $3.6 \times 10^{9}$ mononucleated BMCs via the intracoronary delivery approach [38]. Cells were infused immediately after PCI, which was performed 2 to 6 days after thombolysis. Follow-up at 6 months significantly demonstrated an improved left ventricular ejection fraction of 5\% compared with the control group. The REGENT trial (myocardial REGENeraT by intracoronary infusion of selected population of stem cells in acute myocardial infarction) examined 200 patients with anterior wall acute myocardial infarctions, randomizing patients to either placebo or intracoronary infusion of $1.7 \times 10^{8}$ unselected mononucleated BMCs or $1.9 \times 10^{6}$ enriched CXRR4+CD34+ progenitor mononucleated BMCs 7 days, on average, following primary PCI [39]. Left ventricular function assessed by MRI at 6-month follow-up demonstrated a $3 \%$ improvement in ejection fraction in the cell-therapy-treated group versus control, suggesting that bone marrow populations containing progenitor cell surface markers could be responsible for the observed effects.

The largest trial involving intracoronary delivery for chronic ischemic heart disease was TOPCARE-CHD (Transplantation Of Progenitor Cells And Regeneration Enhancement in Chronic ischemic Heart Disease), which enrolled 75 patients with ischemic heart failure [40]. Patients were randomized to receive placebo or a cell intracoronary cell infusion of $2.0 \times 10^{8}$ mononucleated BMCs or circulating blood-derived progenitor cells into the patent coronary artery supplying the most dyskinetic left ventricular area. At 3-month follow-up, left ventricular function, assessed by contrast angiography, was improved by $2.9 \%$ in patients receiving the BMCs versus patients receiving either circulating blood-derived progenitor cells or placebo.

\section{Unresolved issues regarding intracoronary delivery}

It is estimated that following a typical myocardial infarction one billion or more cardiomyocytes are lost [41]. Replacing even a fraction of the lost cells is challenging. The results from the largest first generation clinical studies examining the benefit of stem/progenitor cell therapy delivered via the intracoronary route suggests that cell transplantation results in a mild short-term improvement in left ventricular function. More recent data from Yousef and colleagues [42] demonstrated significant clinical benefit and decreased mortality up to 5 years after BMC infusion. These results should be viewed as preliminary as the studies were relatively small in size, and it is unresolved whether these mild improvements in left ventricular function will translate into sustained clinical improvements in morbidity and mortality. 
The optimal intracoronary delivery parameters have not been determined nor whether intracoronary delivery is the optimal delivery route. Unfortunately, the early excitement demonstrating the promise of regenerative cell therapy has led to design and implementation of multiple clinical trials examining the efficacy of cellular cardiomyoplasty in the absence of data regarding the most efficacious stem or progenitor cell, optimal cell isolation protocols, dose of delivered cells, timing of delivery, location of delivery (normal myocardium, ischemic border zone [43] or infarcted zone), method of delivery, and methods to evaluate outcome and determination of the proper endpoint. Indeed, even in animal models the diagnostic approaches to determine engraftment and tracking of cells are not optimal and may falsely overestimate cellular engraftment and survival [44]. As such, it has proven difficult to compare results from the various trials or pre-clinical studies. Furthermore, the mechanism by which stem cell delivery improves regional wall motion is incompletely understood. Several preclinical studies in large animal models have demonstrated poor retention and survival of delivered cells within the area of interest/delivery and so a paracrine effect by the infused cells on neighboring cells has been postulated. To date, this paracrine effect has not been clearly elucidated.

For patients presenting with an AMI, the ease of delivery following catheter intervention to re-establish coronary flow certainly makes the intracoronary delivery approach appealing. Future trials will need to establish the optimal timing for delivery following myocardial infarction to maximally affect clinical outcomes. Dose ranging studies to determine the most efficacious dose for intracoronary delivery will also need to be performed. In studies evaluating intramyocardial delivery in a porcine model of infarction, a dose-response effect was not demonstrated [45]. Likewise, in human clinical trials using an intracoronary delivery approach no correlation between infused cell number and infarct size reduction or improvement in ejection fraction has been observed [42].

While preclinical animal studies suggest that by optimizing delivery pressures and duration using a single infusion at $20 \mathrm{ml} / \mathrm{minute}$ results in similar engraftment, improved blood flow and decreased mortality, optimal delivery pressures and duration for human intracoronary delivery are not currently known [27]. Also, successful intracoronary delivery of cells is dependent upon transendothelial passage and migration into the myocardium. The observed poor engraftment rates are likely a reflection of the poor efficiency of this process and poor cell survival rates, highlighting the importance of the cellular milieu that favors these events.

Pre-clinical and clinical investigations to determine cellular or biochemical factors to enhance the efficiency of these processes will likely result in improved cell engraftment. One approach to improve cellular engraftment may be to align the stromal cell-derived factor (SDF)-1/chemokine receptor 4 (CXCR4) axis [46]. SDF-1 is a CXC chemokine constitutively produced by bone marrow cells and the interaction of SDF-1 and its receptor CXCR4 may be of critical importance in cellular engraftment of BMCs within ischemic myocardium [47]. In the setting of ischemia both SDF-1 and CXCR4 are upregulated [48]. Recruitment and engraftment of BMCs is thereby enhanced. However, SDF-1 expression in the myocardium increases early after infarction, declining 4 to 7 days after infarction, while cellular expression of CXCR4 [47] occurs in mature BMCs, thereby taking days to achieve expression levels high enough to improve engraftment. Hence, there may be a SDF-1a/CXCR4 malalignment within ischemic myocardium that precludes adequate BMC engraftment. By aligning temporally the SDF-1/CXCR4 axis it may be possible to increase myocardial BMC engraftment. Finally, if the 'paracrine effect' appears to be a major mechanism of benefit, it needs to be further investigated. Hopefully, improvement in these areas will lead to greater cell engraftment, greater improvement in myocardial function and better clinical outcomes.

\section{Conclusion}

If successful, BMC delivery to the infarcted or chronically ischemic patient has the potential to reduce mortality rates and clinical symptoms. Indeed, the hope is to reduce progression to congestive heart failure and the incidence of ventricular arrhythmias resulting from large myocardial infarctions. It could be possible that delivery of a relatively small concentration of stem cells to the arrhythmogenic focus could reduce the likelihood of recurrent life-threatening ventricular tachycardia. The possibilities are great but the important and more scientifically boring questions examining fundamentals of myocardial delivery and optimization of stem cells need to be answered. As a result, there is a risk that the promise inherent in this approach may never be actualized.

\section{Abbreviations}

$\mathrm{AMI}=$ acute myocardial infarction; $\mathrm{BMC}=$ bone-marrow-derived cell; $\mathrm{CXCR}=$ chemokine receptor; $\mathrm{MRI}=$ magnetic resonance imaging; $\mathrm{MSC}=$ mesenchymal stem cell; $\mathrm{PCI}=$ percutaneous coronary intervention; SDF = stromal cell-derived factor.

\section{Competing interests}

RW has equity interest in Johnson \& Johnson. The other authors declare that they have no competing interests.

\section{Authors' contributions}

ZG contributed to the section 'Cell delivery methods' and was responsible for writing those subsections detailing the different methods of stem cell delivery. For the remainder of the paper QB and RW contributed equally in conceiving and writing the manuscript. 
Published: 23 September 2010

\section{References}

1. Rosamond W, Flegal K, Friday G, Furie K, Go A, Greenlund K, Haase N, Ho M, Howard V, Kissela B, Kittner S, Lloyd-Jones D, McDermott M, Meigs J, Moy C, Nichol G, O'Donnell CJ, Roger V, Rumsfeld J, Sorlie P, Steinberger J, Thom T, Wasserthiel-Smoller S, Hong Y; American Heart Association Statistics Committee and Stroke Statistics Subcommittee: Heart disease and stroke statistics - 2007 update: a report from the American Heart Association Statistics Committee and Stroke Statistics Subcommittee. Circulation 2007, 115:e69-171.

2. He J, Ogden LG, Bazzano LA, Vupputuri S, Loria C, Whelton PK: Risk factors for congestive heart failure in US men and women: NHANES I epidemiologic follow-up study. Arch Intern Med 2001, 161:996-1002.

3. Lloyd-Jones D, Adams R, Carnethon M, De Simone G, Ferguson TB, Flegal K, Ford E, Furie K, Go A, Greenlund K, Haase N, Hailpern S, Ho M, Howard V, Kissela B, Kittner S, Lackland D, Lisabeth L, Marelli A, McDermott M, Meigs J, Mozaffarian D, Nichol G, O'Donnell C, Roger V, Rosamond W, Sacco R, Sorlie P, Stafford R, Steinberger J, Thom T, Wasserthiel-Smoller S, Wong N, Wylie-Rosett J, Hong Y: American Heart Association Statistics Committee and Stroke Statistics Subcommittee: American Heart Association Statistics Committee and Stroke Statistics Subcommittee. Heart disease and stroke statistics - 2009 update: a report from the American Heart Association Statistics Committee and Stroke Statistics Subcommittee. Circulation 2009, 119:e21-181.

4. Abdel-Latif A, Bolli R, Tleyjeh IM, Montori VM, Perin EC, Hornung CA, ZubaSurma EK, Al-Mallah M, Dawn B: Adult bone marrow-derived cells for cardiac repair: a systemic review and meta-analysis. Arch Intern Med 2007 167:989-997.

5. Hristov M. Heussen N, Schober A, Weber C: Intracoronary infusion of autologous bone marrow cells and left ventricular function after acute myocardial infarction: a meta-analysis. J Cell Mol Med 2006, 10:727-733.

6. Lipinski MJ, Biondi-Zoccai GG, Abbate A, Khianey R, Sheiban I, Bartunek J, Vanderheyden M, Kim HS, Kang HJ, Strauer BE, Vetrovec GW: Impact of intracoronary cell therapy on left ventricular function in the setting of acute myocardial infarction: a collaborative systemic review and metaanalysis of controlled clinical trials. J Am Coll Cardiol 2007, 50:1761-1767.

7. Martin-Rendon E, Brunskill SJ, Hyde CJ, Stanworth SJ, Mathur A, Watt SM: Autologous bone marrow stem cells to treat acute myocardial infarction: a systematic review. Eur Heart J 2008, 29:1807-1818.

8. Joggerst $\mathrm{SJ}$, Hatzopoulos AK: Stem cell therapy for cardiac repair: benefits and barriers. Expert Rev Mol Med 2009, 8:e20-39.

9. Gersh BJ, Simari RD, Behfar A, Terzic CM, Terzic A: Cardiac cell repair therapy: a clinical perspective. Mayo Clin Proc 2009, 84:876-892.

10. Mayo Clin Proc.Orlic D, Kajstura J, Chimenti S, Jakoniuk I, Anderson SM, Li B, Pickel J, McKay R, Nadal-Ginard B, Bodine DM, Leri A, Anversa P: Bone marrow cells regenerate infracted myocardium. Nature 2001, 410:701-705.

11. Rota M, Kajstura J, Hosoda T, Bearzi C, Vitale S, Esposito G, laffaldano G, PadinIruegas ME, Gonzalez A, Rizzi R, Small N, Muraski J, Alvarez R, Chen X, Urbanek K, Bolli R, Houser SR, Leri A, Sussman MA, Anversa P: Bone marrow cells adopt the cardiomyogenic fate in vivo. Proc Natl Acad Sci U S A 2007, 104:17783-17788

12. Balsam LB, Wagers AJ, Christensen JL, Kofidis T, Weissman IL, Robbins RC: Haematopoietic stem cells adopt mature haemotopoietic fates in ischaemic myocardium. Nature 2004, 428:668-673.

13. Orlic D, Kajstura J, Chimenti S, Limana F, Jakoniuk I, Quaini F, Nadal-Ginard B, Bodine DM, Leri A, Anversa P: Mobilized bone marrow cells repair the infarcted heart, improving function and survival. Proc Natl Acad Sci U S A 2001, 98:10344-10349.

14. Menasche P: Stem cells for clinical use in cardiovascular medicine. Thromb Haemost 2005, 94:697-701

15. Korf-Klingebiel M, Kempf T, Sauer T, Brinkmann E, Fischer P, Meyer GP, Ganser A, Drexler H, Wollert KC: Bone marrow cells are a rich source of growth factors and cytokines: implications for cell therapy trials after myocardial infarction. Eur Heart J 2008, 29:2851-2858

16. Murry CE, Soonpaa MH, Reinecke H, Nakajima $H$, Nakajima HO, Rubart M, Pasumarthi KB, Virag Jl, Bartelmez SH, Poppa V, Bradford G, Dowell JD, Williams DA, Field L: Haematopoietic stem cells do not transdifferentiate into cardiac myocytes in myocardial infarcts. Nature 2004, 428:664-668.

17. Gnecchi M, Zhang Z, Ni A, Dzau VJ: Paracrine mechanisms in adult stem cell signaling and therapy. Circ Res 2008, 103:1204-1219.
18. Kocher AA, Schuster MD, Szabolcs MJ, Takuma S, Burkhoff D, Wang J, Homma S, Edwards NM, Itescu S: Neovascularization of ischemic myocardium by human bone-marrow-derived angioblasts prevents cardiomyocytes apoptosis, reduces remodeling and improves cardiac function. Nat Med 2001, 7:430-436

19. Barbash IM, Chouraqui P, Baron J, Feinberg MS, Etzion S, Tessone A, Miller L, Guetta E, Zipori D, Kedes LH, Kloner RA, Leor J: Systemic delivery of bone marrow-derived mesenchymal stems cells to the infracted myocardium: feasibility, cell migration, and body distribution. Circulation 2003, 108:863-868.

20. Wollert KC, Drexler $\mathrm{H}$ : Cell therapy for the treatment of coronary heart disease: a critical appraisal. Nat Rev Cardiol 2010, 7:204-215.

21. Perin EC, Silva GV, Fernandes MR, Munger T, Pandey A, Sehra R, Talcott M, Bichard CJ, Creed J, Wong JW, Oliveira EM, Zheng Y, Canales J, Cardoso CO, Patterson MS, Serruys PW: First experience with remote left ventricular mapping and transendocardial cell injection with a novel integrated magnetic navigation-guided electromechanical mapping system. Eurolntervention 2007, 3:142-148,

22. George JC, Goldberg J, Joseph M, Abdulhameed N, Crist J, Das H, Pompili VJ: Transvenous intramyocardial cellular delivery increases retention in comparison to intracoronary delivery in a porcine model of acute myocardial infarction. J Interv Cardiol 2008, 2:424-431.

23. Raake P, von Degenfeld G, Hinkel R, Vachenauer R, Sandner T, Beller S, Andrees M, Kupatt C, Schuler G, Boekstegers P: Myocardial gene transfer by selective pressure-regulated retrofusion of coronary veins: comparison with surgical and percutaneous intramyocardial gene delivery. J Am Coll Cardiol 2004, 44:1124-1129.

24. Branco E, Fioretto ET, Cabral R, Palmera CA, Gregores GB, Stopiglia AJ, Maiorka PC, Lemos PA, Campos C, Takimura C, Ramires JA, Miglino MA: Myocardial homing after intrapericardial infusion of bone marrow mononuclear cells. Ara Bras Cardiol 2009, 93:e50-53.

25. Hou D, Youssef EA, Brinton TJ, Zhang P, Rogers P, Price ET, Yeung AC, Johnstone $\mathrm{BH}$, Yock PG, March KL: Radiolabeled cell distribution after intramyocardial, intracoronary, and interstitial retrograde coronary venous delivery: implications for current clinical trials. Circulation 2005, 112 (9 Suppl):1150-156

26. Freyman T, Polin G, Osman H, Crary J, Lu M, Cheng L, Palasis M, Wilensky RL: A quantitative, randomized study evaluating three methods of mesenchymal stem cell delivery following myocardial infarction. Eur Heart J 2006, 27:1114-1122.

27. Llano R, Epstein S, Zhou R, Zhang H, Hamamdzic D, Keane MG, Freyman T, Wilensky RL: Intracoronary delivery of mesenchymal stem cells at high flow after myocardial infarction improves distal coronary blood flow and decreases mortality in pigs. Catheter Cardiovasc Interv 2009, 73:251-257.

28. Niccoli, G, Burzotta, F, Galiuto, Crea F: Myocardial no-reflow in humans. J Am Coll Cardiol 2009, 54:281-292.

29. Perin EC, Silva GV, Assad JA, Vela D, Buja LM, Sousa AL, Litovsky S, Lin J, Vaughn WK, Coulter S, Fernandes MR, Willerson JT: Comparison of intracoronary and transendocardial delivery of allogeneic mesenchymal cells in a canine model of acute myocardial infarction. J Mol Cell Cardiol 2008, 44:486-495.

30. Vulliet PR, Greeley M, Halloran SM, MacDonald KA, Kittleson MD: Intracoronary arterial injection of mesenchymal stromal cells and microinfarction in dogs. Lancet 2004, 363:783-784.

31. Janssens S, Dubois C, Bogaert J, Theunissen K, Deroose C, Desmet W, Kalantz M, Herbots L, Sinnaeve P, Dens J, Maertens J, Rademakers F, Dymarkowski S, Gheysens O, Van Cleemput J, Bormans G, Nuyts J, Belmans A, Mortelmans L, Boogaerts M, Van de Werf F: Autologous bone marrow-derived stem-cell transfer in patients with ST-segment elevation myocardial infarction: double-blind, randomized controlled trial. Lancet 2006, 14:113-121.

32. Wollert KC, Meyer GP, Lotz J, Ringes-Lichtenberg S, Lippolt P, Breidenbach C, Fichtner S, Korte T, Hornig B, Messinger D, Arseniev L, Hertenstein B, Ganser A, Drexler $\mathrm{H}$ : Intracoronary autologous bone-marrow cell transfer after myocardial infarction: the BOOST randomized controlled trial. Lancet 2004, 364:141-148.

33. Schächinger V, Erbs S, Elsässer A, Haberbosch W, Hambrecht R, Hölschermann H, Yu J, Corti R, Mathey DG, Hamm CW, SüselbeckT, Assmus B, Tonn T, Dimmeler S, Zeiher AM; REPAIR-AMI Investigators: Intracoronary bone marrow-derived progenitor cells in acute myocardial infarction. $N$ Eng/ $\mathrm{J}$ Med 2006, 355:1210-1221

34. Strauer BE, Brehm M, Zeus T, Köstering M, Hernandez A, Sorg RV, Kögler G, 
Wernet $P$ : Repair of infarcted myocardium by autologous intracoronary mononuclear bone marrow cell transplantation in humans. Circulation 2002, 106:1913-1918.

35. Hirsch A, Nijveldt R, van der Vleuten PA, Tio RA, van der Giessen WJ, Marques KM, Doevendans PA, Waltenberger J, Ten Berg JM, Aengevaeren WR, Biemond BJ, Tijssen JG, van Rossum AC, Piek JJ, Zijlstra F: Intracoronary infusion of autologous mononuclear bone marrow cells in patients with acute myocardial infarction treated with primary PCl: pilot study of the multicenter HEBE trial. Catheter Cardiovas Interv 2008, 71:273-281.

36. García-Dorado D, Oliveras J, Gili J, Sanz E, Pérez-Villa F, Barrabés J, Carreras MJ, Solares J, Soler-Soler J: Analysis of myocardial oedema by magnetic resonance imaging early after coronary artery occlusion with or without reperfusion. Cardiovasc Res 1993, 27:1462-1469.

37. Dill T, Schächinger $V$, Rolf A, Möllmann S, Thiele H, Tillmanns H, Assmus B, Dimmeler S, Zeiher AM, Hamm C: Intracoronary administration of bone marrow-derived progenitor cells improve left ventricular function in patients at risk for adverse remodeling after acute ST-segment elevation myocardial infarction: results of the Reinfusion of Enriched Progenitor cells And Infarct Remodeling in Acute Myocardial Infarction study (REPAIR-AMI) cardiac magnetic resonance imaging substudy. Am Heart J 2009, 157:541-547.

38. Huikuri HV, Kervinen K, Niemelä M, Ylitalo K, Säily M, Koistinen P, Savolainen ER, Ukkonen H, Pietilä M, Airaksinen JK, Knuuti J, Mäkikallio TH; FINCELL Investigators: Effects of intracoronary injection of mononuclear bone marrow cells on left ventricular function, arrhythmia risk profile, and restenosis after thrombolytic therapy of acute myocardial infarction. Eur Heart J 2008, 29:2723-2732.

39. Tendera M, Wojakowski W, Ruzyłło W, Chojnowska L, Kepka C, Tracz W, Musiałek P, Piwowarska W, Nessler J, Buszman P, Grajek S, Breborowicz P, Majka $M$, Ratajczak MZ; REGENT Investigators: Intracoronary infusion of bone marrow-derived selected CD34+ CXCR4+ cells and non-selected mononuclear cells in patients with acute STEMI and reduced left ventricular ejection fraction: results of randomized, multicenter Myocardial Regeneration by Intracoronary Infusion of Selected Population of Stem Cells in Acute Myocardial Infarction (REGENT) trial. Eur Heart $J$ 2009, 30:1313-1321.
40. Assmus B, Honold J, Schächinger V, Britten MB, Fischer-Rasokat U, Lehmann R, Teupe C, Pistorius K, Martin H, Abolmaali ND, Tonn T, Dimmeler S, Zeiher AM: Transcoronary transplantation of progenitor cells after myocardial infarction. N Engl J Med 21, 355:1222-1232.

41. Laflamme MA, Murry CE: Regenerating the heart. Nat Biotechnol 2005, 23:845-856.

42. Yousef M, Schannwell CM, Köstering M, Zeus T, Brehm M, Strauer BE: The BALANCE Study. Clinical benefit and long-term outcome after intracoronary autologous bone marrow cell transplantation in patients with acute myocardial infarction. J Am Coll Cardiol 2009, 53:2262-2269.

43. Orlic D, Kajstura J, Chimenti S, Bodine DM, Leri A, Anversa P: Bone marrow cells regenerate infarcted myocardium. Nature 2001, 410:701-705

44. Terrovitis JV, Smith RR, Marban E: Assessment and optimization of cell engraftment after transplantation into the heart. Circ Res 2010, 106:479-494.

45. Hashemi SM, Ghods S, Kolodgie FD, Parcham-Azad K, Keane M, Hamamdzic D, Young R, Rippy MK, Virmani R, Litt H, Wilensky RL: A placebo controlled dose-ranging, safety study of allogenic mesenchymal stem cells injected by endomyocardial delivery after an acute myocardial infarction. Eur Heart J 2008, 29:251-259.

46. Penn MS: Importance of the SDF-1:CXCR4 axis in myocardial repair. Circ Res 2009, 104:1133-1135.

47. Askari AT, Unzek S, Popovic ZB, Goldman CK, Forudi F, Kiedrowski M, Rovner A, Ellis SG, Thomas JD, DiCorleto PE, Topol EJ, Penn MS: Effect of stromal-cellderived factor 1 on stem-cell homing and tissue regeneration in ischaemic cardiomyopathy. Lancet 2003, 362:697-703.

48. Tang YL, Zhu W, Cheng M, Chen L, Zhang J, Sun T, Kishore R, Phillips MI, Losordo DW, Qin G: Hypoxic preconditioning enhances the benefit of cardiac progenitor cell therapy for treatment of myocardial infarction by inducing CXCR4 expression. Circ Res 2009, 104:1209-1216.

doi:10.1186/scrt29

Cite this article as: Bui QT, et al:: Intracoronary delivery of bone-marrowderived stem cells. Stem Cell Research \& Therapy 2010, 1:29. 